\title{
Public knowledge and attitudes towards consent policies for organ donation in Europe. A systematic review
}

\author{
Alberto Molina-Pérez ${ }^{\mathrm{a}, \mathrm{b}, *, 1}$, David Rodríguez-Arias ${ }^{\mathrm{a}, \mathrm{b}, 1}$, Janet Delgado-Rodríguez ${ }^{\mathrm{a}, \mathrm{c}}$, Myfanwy Morgan ${ }^{\mathrm{a}, \mathrm{d}}$, \\ Mihaela Frunza a,e, Gurch Randhawa a,f Jeantine Reiger-Van de Wijdeven a,g, Eline Schiks ${ }^{\mathrm{a}, \mathrm{h}}$, \\ Sabine Wöhlke ${ }^{\text {a,i }}$, Silke Schicktanz ${ }^{\text {a,i }}$ \\ a Ethical Legal and Psychosocial Aspects of organ Transplantation (ELPAT), a section of the European Society for Organ Transplantation (ESOT)

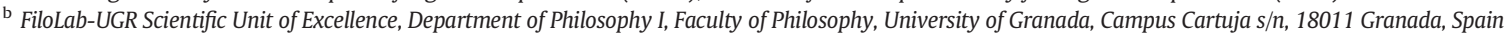 \\ c University Hospital of Canary Island, University of La Laguna, Tenerife, Spain \\ d Institute of Pharmaceutical Science, King's College London, United Kingdom \\ e Department of Philosophy, Faculty of History and Philosophy, Babes-Bolyai University of Cluj, Cluj, Romania \\ ${ }^{\mathrm{f}}$ Institute for Health Research, University of Bedfordshire, Luton, England, United Kingdom \\ ${ }^{g}$ Dutch Transplant Foundation, Department of Public Information \&' Education, Leiden, the Netherlands \\ ${ }^{\text {h }}$ Dutch Transplant Foundation, Department of Policy, Leiden, the Netherlands \\ ${ }^{i}$ Department of Medical Ethics and History of Medicine, University Medical Center Göttingen, Göttingen, Germany
}

\section{Contents}

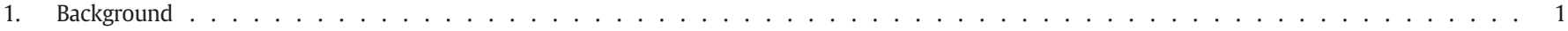

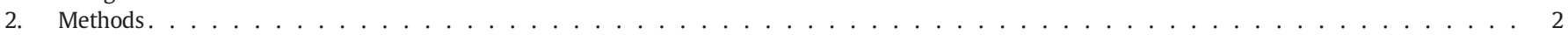

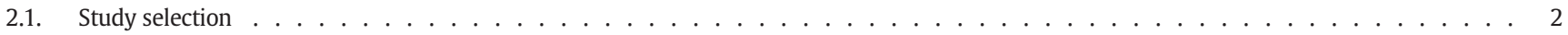

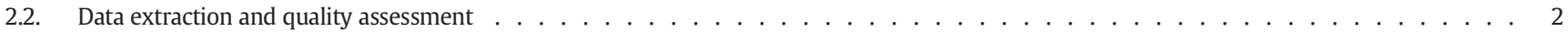

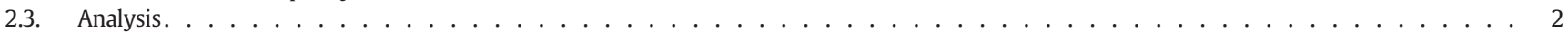

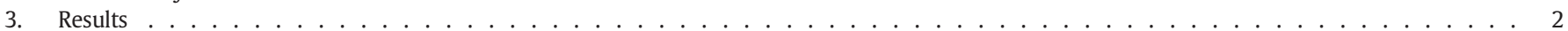

3.1. Knowledge of the model of consent . . . . . . . . . . . . . . . . . . . . . . . . . . .

3.2. Knowledge of procedures to express preferences . . . . . . . . . . . . . . . . . . . . . . . . . . . 3

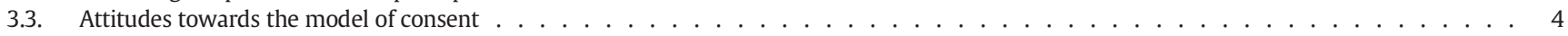

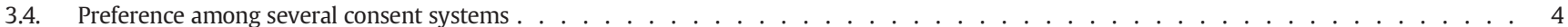

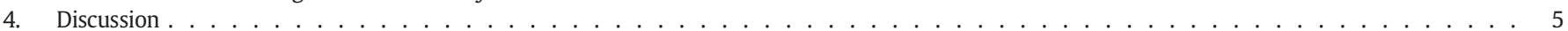

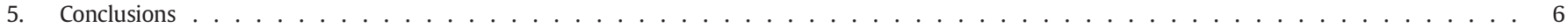

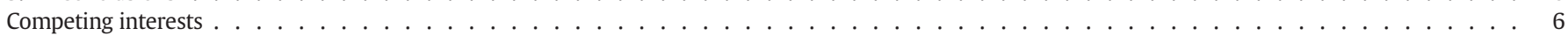

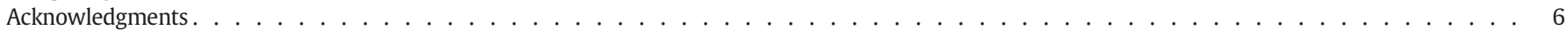

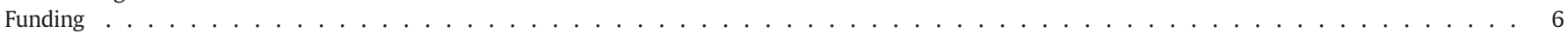

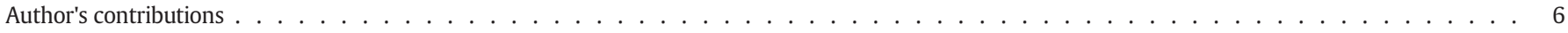

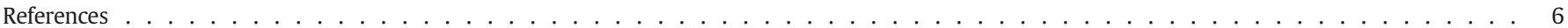

Included studies $\ldots \ldots \ldots \ldots \ldots \ldots$

\section{Background}

In Europe, opt-out policies (i.e. presumed consent) for deceased organ procurement are an increasingly common strategy to address the organ shortage (Additional file Table 1). Under opt-out laws, individuals are automatically considered donors after death unless they have explicitly objected during their lifetime. Some European countries have had this system for several years (e.g. Spain, Austria) and others have recently considered or achieved legislative changes

\footnotetext{
* Corresponding author at: Departamento de Filosofía 1, Facultad de Filosofía, Universidad de Granada, 18011 Granada, Spain.

E-mail address: albertomolina@ugr.es (A. Molina-Pérez).

${ }^{1}$ Contributed equally
}

(Table 1). Scotland and England have recently carried out public consultations regarding a change to the opt-out system [1,2].

In opt-in countries -where a donor card or registration as donor is required,- information and public knowledge are important for organ donation rates, as people will only donate if they are aware of their active part in consenting. In opt-out countries, some have claimed that broad publicity and information of that model should also be made available for ethical reasons, given that autonomous choices require understanding the consequences of expressed and non-expressed preferences [3,4]. Assessing public awareness and attitudes towards models of consent for organ procurement has both policy and ethical relevance.

A 2009 Special Eurobarometer survey indicated that only 28\% of individuals residing in Europe were aware of the laws governing 
Table 1

Consent models of the countries included in this review. The date refers to the earliest known law regulating the consent system. As for most recent changes (Greece and Wales), the implementation date is indicated.

\begin{tabular}{lll}
\hline Country & Type of consent & Date \\
\hline Austria & Opt-out & 1982 \\
Denmark & Opt-in & 1990 \\
France & Opt-out & 1976 \\
Germany & Opt-in & $1997^{\mathrm{d}}$ \\
Greece & Opt-out ${ }^{\mathrm{a}}$ & $2011 / 13^{\mathrm{e}}$ \\
Iceland & Opt-in & 1991 \\
Ireland & Opt-in & $\mathrm{n} / \mathrm{a}$ \\
Malta & Opt-in & 2012 \\
The Netherlands & Opt-in & 1996 \\
Poland & Opt-out & 1990 \\
Romania & Opt-in & 1998 \\
Serbia & Opt-in & 1996 \\
Spain & Opt-out & 1979 \\
Sweden & Opt-out & 1996 \\
UK (England, N. Ireland, Scotland) & Opt-in & 1961 \\
Wales & Opt-out & $2013 / 15^{\mathrm{e}}$ \\
\hline
\end{tabular}

a Greece implemented its opt-out system during the period covered by this review, and we found studies conducted before and after the legal change.

b The Netherlands passed a law in 2018, which will be implemented in 2020, to move from opt-in to opt-out.

c Wales implemented its opt-out system in December 2015, but all Welsh studies relevant for this review have been conducted before that date while the country had an optin system.

$\mathrm{d}$ The consent model was already in place before that date.

e Dates of law's votation and implementation.

donation and transplantation of organs in their country [5], but was unspecific about which aspects of organ donation and transplant legislations were investigated (e.g. death determination, organ allocation criteria, the model of consent for OD, etc.). Many studies have explored public attitudes towards organ donation [6-11]. Others have investigated the impact of different consent systems on donation rates [12-25]. However, the level of public knowledge and support of national policies on consent for deceased organ donation has not been systematically studied. The only comprehensive analysis of attitudes towards presumed consent was a systematic review by Rithalia et al. in 2008, followed by an update in 2012 [20,26]. This review contributed to a UK Taskforce recommendation "that an opt-out system should not be introduced in the UK" because of its "potential to undermine the concept of donation as a gift, to erode trust in NHS professionals and the Government, and negatively impact on organ donation numbers" [27]. It did not address other models of consent for OD apart from opt-out.

Given the ongoing need for public discussions and to tackle the issue of organ transplantation in Europe, we have conducted a more recent systematic review (2008-2017) to gain evidence on public knowledge and attitudes towards models of consent for deceased organ donation in Europe.

\section{Methods}

\subsection{Study selection}

We followed a seven-step approach for systematic reviews of empirical studies in bioethics, including the MIP model (methodology, issues, participants) to define research questions and inclusion/exclusion criteria [28]. We sought both quantitative and qualitative empirical studies addressing either knowledge or attitudes towards the systems of consent for post-mortem OD by lay people in Europe. Full details of the search strategy, selection criteria, data extraction and quality assessment are available in an additional file.

The search was focused on publications from January 2008 to December 1st, 2017. The following databases were consulted without language restrictions: CINHAL Complete (EBSCO), MEDLINE (Ovid), PAIS Index (ProQuest), PsycINFO (ProQuest), Scopus, and Web of Science (all databases). Additional grey literature reports were searched manually. Nine authors participated independently in the relevance assessment of retrieved articles in three steps: (1) by title only, (2) by title $\&$ abstract, and (3) by full-text.

\subsection{Data extraction and quality assessment}

Data extraction and quality assessment were undertaken by two or more authors following a list of explicit criteria (Additional file) $[29,30]$. Any differences were discussed and a consensus reached. We accepted peer-reviewed articles with disclosed response rates above $20 \%$ when there was no other reason to exclude them. Those with low response rate are duly mentioned with an asterisk $\left({ }^{*}\right)$.

\subsection{Analysis}

A statistical metadata analysis was not possible because of variations in survey questions and sampling. We therefore undertook a descriptive analysis of quantitative studies, with qualitative findings used to identify reasons for differing attitudes. The primary outcome measure was the difference in knowledge and attitudes between opt-in and opt-out countries towards the prevailing consent system. Risk of bias was assessed by comparing sampling and other methodological aspects of studies conducted in opt-in and opt-out countries.

\section{Results}

The search yielded 1,482 citations, with 467 assessed in full-text form (Fig. 1). Seventy studies were eventually retained, comprising 42 scientific articles and 28 surveys. Ten of these studies deal exclusively with the role of the family and are not included in this qualitative synthesis. The remaining 60 results are numbered according to the following convention: published articles are signalled by the letter "A"; grey literature reports are signalled by the letter " $G$ " (Additional file Table 5). Included studies represent 15 countries (Austria, Denmark, UK, France, Germany, Greece, Iceland, Ireland, Malta, The Netherlands, Poland, Romania, Serbia, Spain and Sweden). Nineteen studies explored specific jurisdictions of the UK (England, Northern Ireland, Scotland or Wales). Overall, 50 studies were quantitative, 7 were qualitative [G2, G4, A15, A23, A24, A27, A29] and 3 mixed methods [G16, G22, G25]. Twelve studies considered only knowledge, 24 considered only attitudes, and 24 considered both.

\subsection{Knowledge of the model of consent}

Knowledge of the model of consent was examined by 19 studies (Fig. 2). Those conducted in opt-in countries were mainly government reports exploring knowledge of the general public ( 7 out of 8 studies), while those conducted in opt-out countries were mainly academic articles that examined students' knowledge ( 9 out of 11 studies), including medical students. Overall, reported awareness of the model of consent was higher in opt-in countries than in opt-out countries (Fig. 2). For instance, around two-thirds of respondents in Northern Ireland [G18] and $82 \%$ in Germany [G11] were aware of their opt-in system. Awareness was especially high among medical students (87.4\%) [A1*]. In opt-out countries, the two studies conducted with the general public identified low awareness of the legislation: less than $10-15 \%$ in Greece in 2013 when the opt-out system was introduced [A32] (Table 1), and 39\% more recently in France [G13]. Students' awareness of the opt-out system was variable, ranging from $16 \%$ in Greece [A33] to $88 \%$ in Austria [A30], with medical students generally more knowledgeable than non-medical students. Qualitative studies (not represented in the figure) also suggest that among people who claim to be aware of the consent system, their understanding of it is often limited [G2, G4]. 


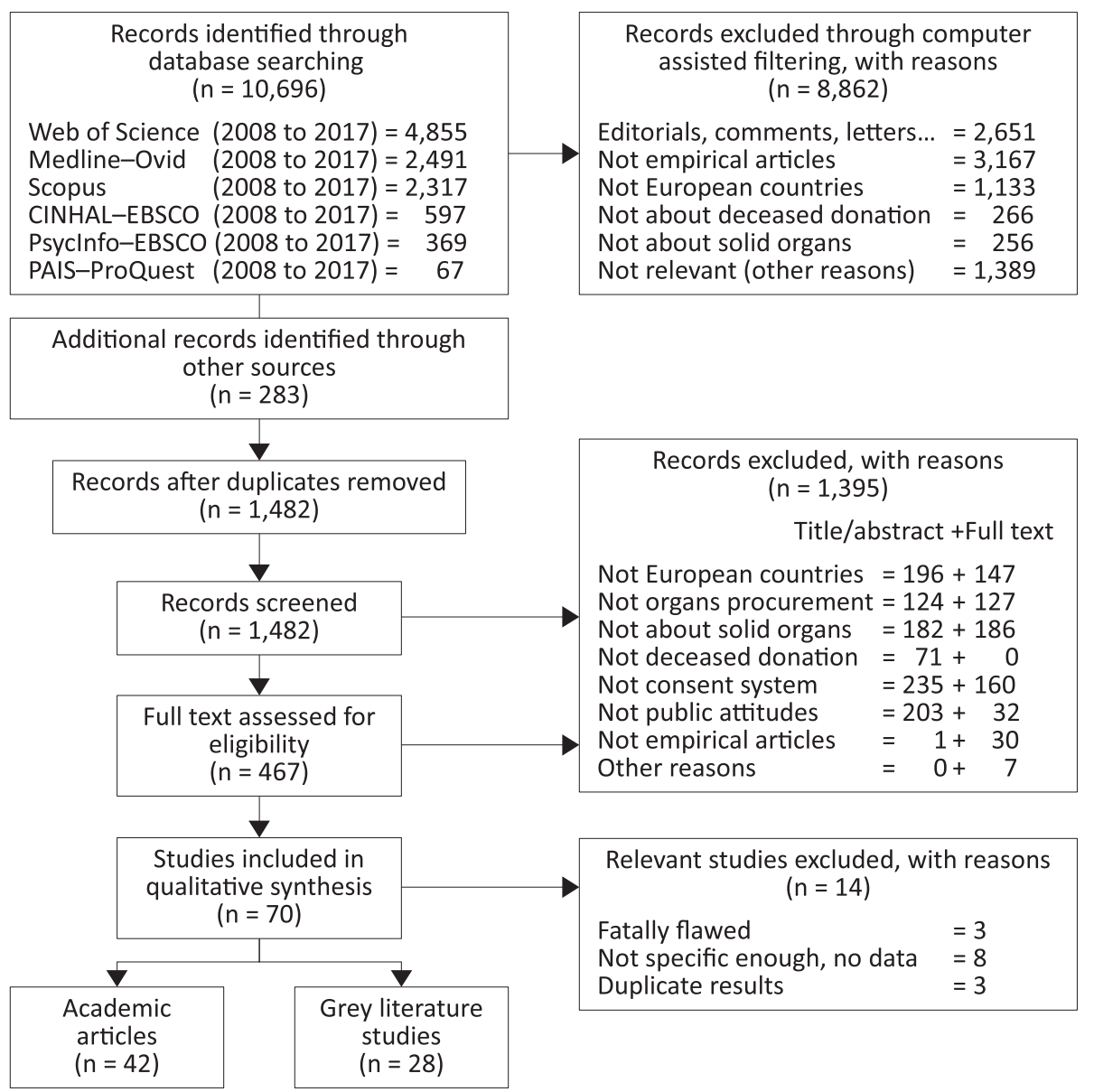

Fig. 1. Flow diagram.

\subsection{Knowledge of procedures to express preferences}

Knowledge of procedures to express preferences was explored by 18 studies conducted in eight countries. Again, most studies in opt-in countries were government reports exploring general public's knowledge, while most in opt-out countries explored students' knowledge. The assessed procedures included organ donor cards (ODC), organ donor registries (ODR), advance directives or declarations of will, and oral communication with relatives. Respondents' knowledge about these procedures was also lower in opt-out countries (France, Poland,

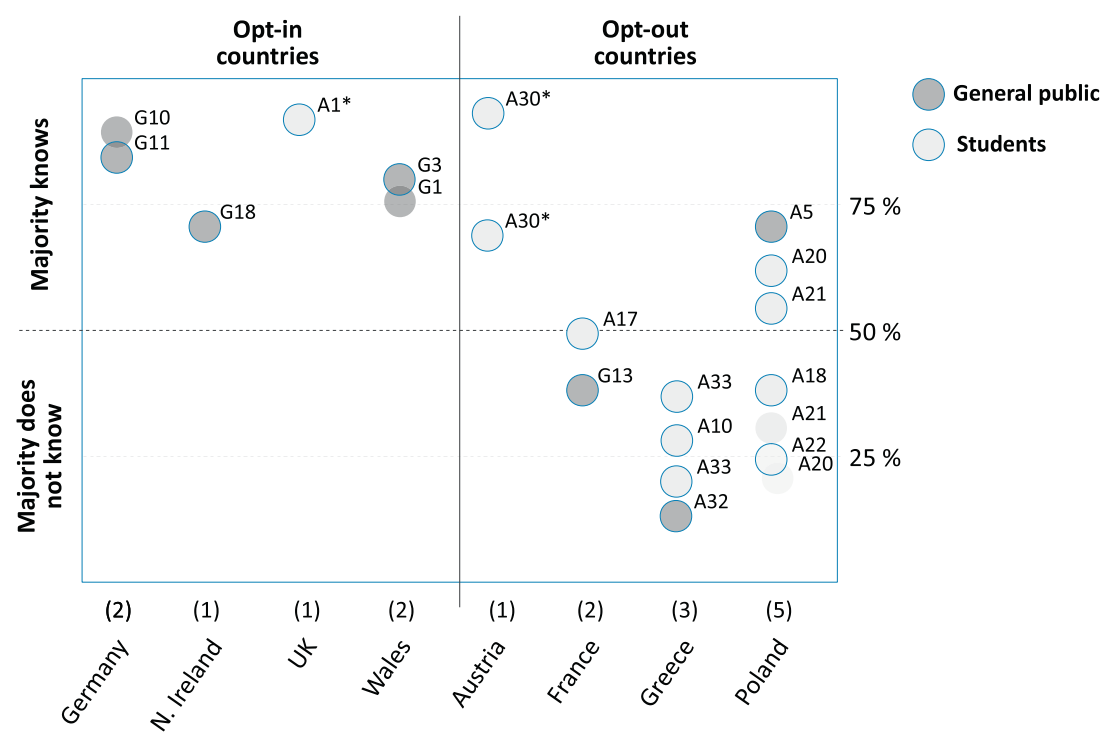

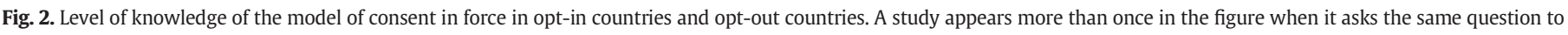
different groups of respondents (A20, A21, A30*, A33). 'A' refers to article and 'G' to grey literature. Quantitative studies alone are represented. 
Sweden) than in opt-in countries (England, Germany, the Netherlands, Northern Ireland). However, the situation varies within some countries, which may be partially due to public campaigns. For example, in Sweden, after two information campaigns, young respondents awareness of the ODRs existence and how to register increased from $18 \%$ in 2001 to $40 \%$ in 2005 [A14].

\subsection{Attitudes towards the model of consent}

Attitudes towards the model of consent were examined by 48 studies. They were mainly undertaken in opt-in countries. We clustered these results into three categories: (1) general attitude towards a specific consent system; (2) preference between two or more consent models; and (3) views of a change in legislation (e.g. from opt-in to opt-out, or from opt-out to opt-in).

A majority of respondents agreed with opt-in -regardless of the consent model in place in their own country- with no differences between students and the general public (Fig. 3). Studies conducted in opt-out countries show overall more agreement towards opt-in than towards opt-out. Studies conducted in opt-in countries show agreement towards opt-in and ambivalence towards opt-out. A majority of respondents in opt-in countries also agreed with mandatory choice, where people are mandated to register a decision, either in favour or against organ donation. Only one study conducted in Germany [A3] examined attitudes to organ conscription (no consent required) and identified $38 \%$ of the general public as expressing agreement with that policy. One survey by the British Medical Association on 2017 has found that $65 \%$ of the public across the UK support opt-out (detailed results of this study were not accessible to us) [31].

The main reason the public gives for favouring opt-out is the increased number of donors and the associated social value of saving lives. Opt-out is also regarded by some as having the advantage of preserving freedom of choice, and being simpler for those in favour of OD, for health care staff to approach patients, and for families, as it removes the burden associated with the decision [G3, G16, G18, G25]. The major concern about opt-out reflects doubts about efficacy, evidence, and ethics [G25]. Ethical concerns relate to the consequences of removing the choice from the individual, to possible infringement of individuals' human rights [A15] and the perceived risk that the medical treatment provided to potential donors could be compromised [G2], resulting in increased public distrust of clinicians [G22]. This is a particular fear regarding vulnerable populations (e.g. individuals with reduced mental capacity and children [G2]). Additional practical concerns about optout include doubts that organ donation registries under this system would be accurate and updated, and the costs of implementing such registries [G2, G25].

\subsection{Preference among several consent systems}

Preference among several consent systems was sought in four opt-in countries (Fig. 4). Results are country-dependent. In Germany, a majority of the public preferred opt-in to opt-out. In the Netherlands, opt-in was preferred over both mandatory choice and opt-out. In Wales the public preferred mandatory choice to opt-out, and opt-out over opt-in. In Scotland the majority also preferred opt-out to opt-in.

Views on a change of the consent system in their country were examined by 19 surveys, most of them in opt-in countries (Fig. 5). The lowest level of support to change to opt-out was in Ireland, in 2008, where $62 \%$ of the population preferred to maintain opt-in [A9]. The highest support for a change to opt-out was registered in Iceland in 2014 , with $80.4 \%$ of respondents in favour, and $11.9 \%$ against [A25]. The results in two opt-out countries (Austria and Poland) were conflicting.

Attitudes towards different procedures to express OD preferences were examined by two studies. In Romania, an opt-in country, $82 \%$ of medicine and pharmacy students supported the idea of using donor cards [A8]. A French survey of lay people who were described as well informed and supportive of OD identified $94 \%$ in favour of creating a registry of refusals [G17].

Two articles explored the relation between knowledge of the model of consent and attitudes towards it, both in opt-out countries. An Austrian survey indicated that $82 \%$ of respondents who knew the law in force were against a legal change [A30*]. By contrast, one study in Poland identified support for informed consent as unrelated to awareness of the current opt-out legislative system in that country [A13].

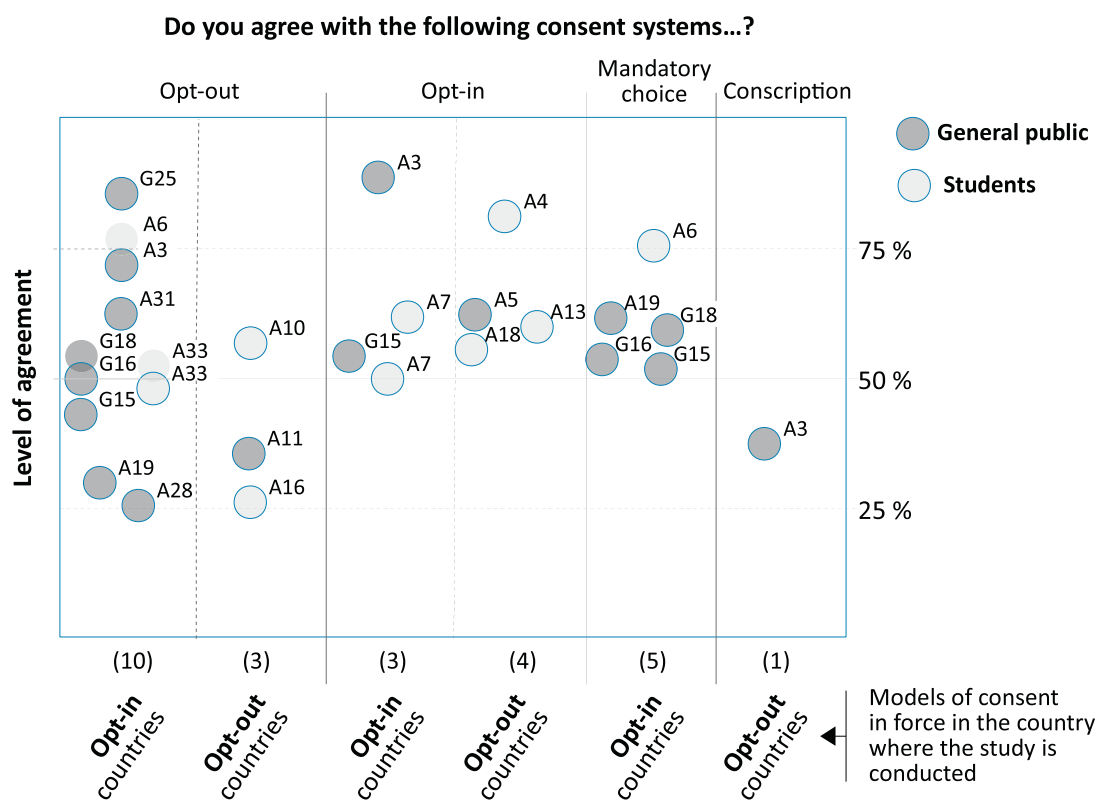

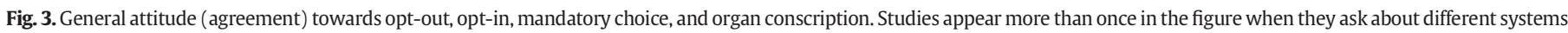
of consent or when they ask the same questions to different groups of respondents (A7, A33). Quantitative studies alone are represented. 


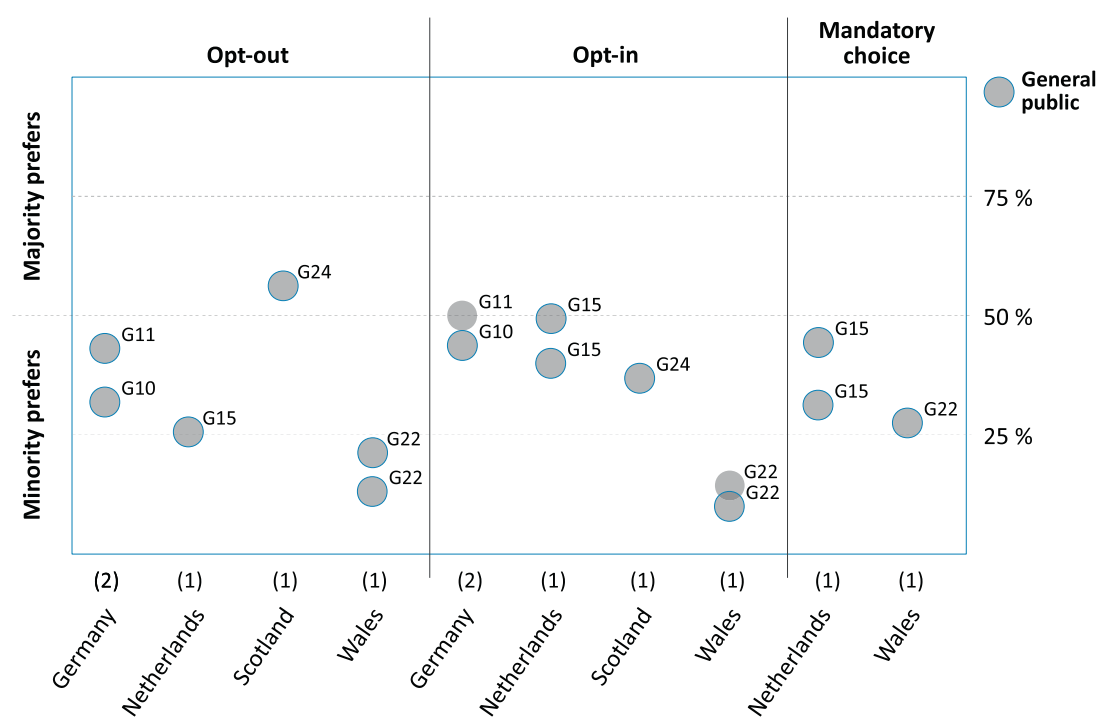

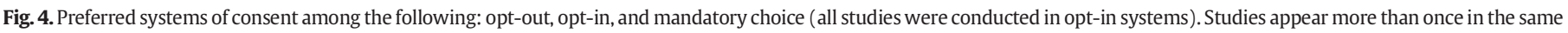
column when respondents are asked about different versions of the same system of consent (G15, G22). Quantitative studies alone are represented.

\section{Discussion}

The relative impact of the model of consent on organ donation rates is controversial. Some have argued that opt-out regulations lead straight to larger pools of organs for transplantation $[4,12,13,15,16,19,22,23]$, while others dispute this claim $[14,17,18,20,21,24,31-35]$. The ethical acceptability of presumed consent is also a debated issue, with arguments in favour [36-39] and against [40-44]. This review explores people's knowledge and attitudes towards the model of consent. This approach is important because the success of any transplant system depends ultimately on public trust and positive attitudes towards organ procurement and transplantation.

Our review reveals that awareness of the model of consent is higher in opt-in countries than in opt-out countries. This may reflect greater efforts in opt-in countries to inform the population through public campaigns to motivate people to donate [45]. In both opt-in and opt-out countries, students -especially those studying health sciences- are more aware than non-students of their consent system. As enhanced education and better knowledge of the system correlates with increased willingness to donate [46], greater efforts in education on the model of consent, and especially among the general public seems an important policy initiative.

There is a question whether increased knowledge of the law in opt-out countries would also increase OD rates or rather lead to a decrease, as donation rates tend to be higher in opt-out countries where the public is less aware of the law [20]. This may thus reflect the default option. Organ procurement without public awareness of opt-out can be viewed as coercive and disrespectful of people's autonomy [44,47]. In contrast, some insist that opt-out preserves individuals' freedom of choice as they could refuse to donate by registering their refusal $[4,48]$. The assumption that people in optout countries are aware of the legal requirements to be excluded from the pool of potential donors is not supported by the results of this review [3].

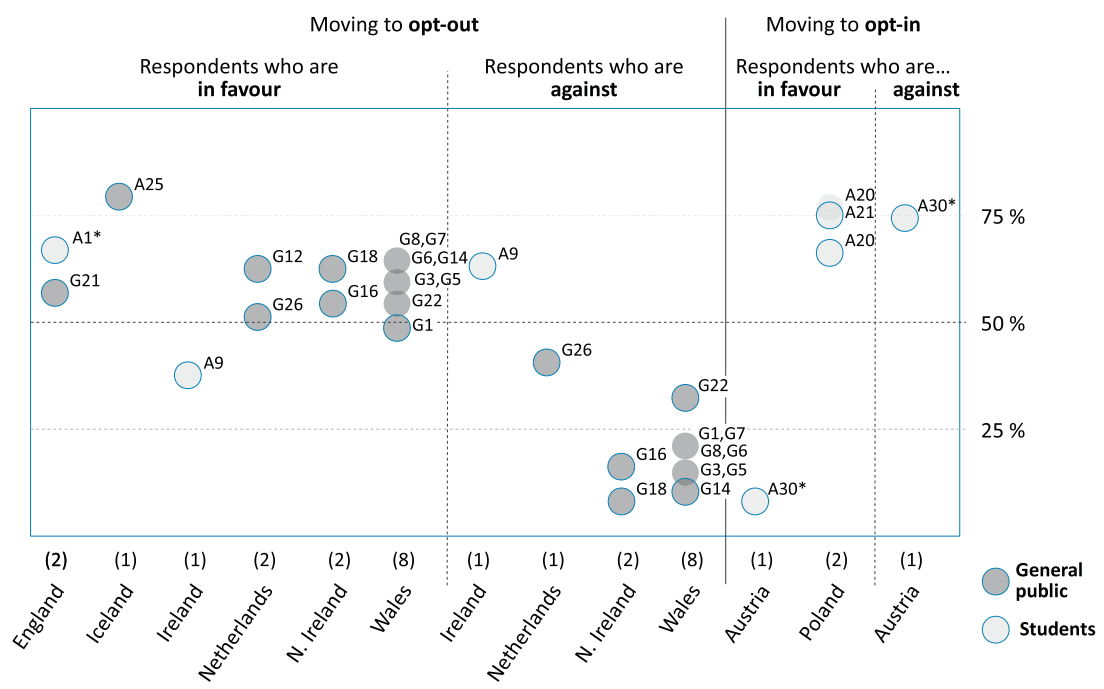

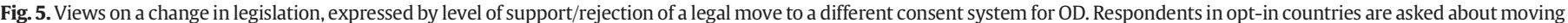
to opt-out. Respondents in opt-out countries are asked about moving to opt-in. Quantitative studies alone are represented. 
Another result of this review is that, while most Europeans support any specific consent system when asked about it separately, they tend to prefer opt-in and mandatory choice to opt-out when they are offered two or more options. The preference expressed in Scotland and Wales towards opt-out over opt-in might be influenced by media campaigns and media attention following the change of policy in Wales.

This systematic review identified several gaps in knowledge. First, the findings for the 15 European countries studied identify a great imbalance regarding the intensity of how the quest for public knowledge was studied between countries. Fifty out of 60 studies have been conducted in only six countries: the UK [23], Poland [9], the Netherlands [7], Germany [4], Greece [4], and France [3]. Most of these are opt-in countries (UK, the Netherlands, Germany) and countries that have recently moved to opt-out (Greece, Wales). This might be explained by a higher policy interest in assessing the level of awareness of their population about the consent system. Moreover, while most studies conducted in opt-in countries explored the knowledge and attitudes of the general population, those conducted in opt-out countries relied mostly on students and small population groups such as prisoners, rural patients, migrants, and religious groups. There is a lack of more general information about public knowledge and attitudes in opt-out countries and the need to assess the findings of studies in relation to their recruited study population. Studying students cannot replace studying the public even though they form an important (and often easier accessible) population.

The results of this review on knowledge and attitudes towards models of consent for organ procurement may not be generalizable or reproducible, as data may have been influenced by a number of factors that are country specific and time dependent, including the proximity of media campaigns in some countries. Assessing the relative impact of such factors would require specific analyses. Our results may have also been influenced by the specific characteristics of each consent system, including the availability of registries [49], and the role given by the law to families of deceased donors [50].

It is also worth noting that, among the studies conducted in opt-in countries, 24 out of 42 are reports (especially Government reports) that cannot be granted the same credibility as peer-reviewed scientific articles. On the other side, among peer-reviewed studies conducted in opt-out countries, only one out of 16 has been conducted on a random sample of the country's population [A14], while 12 out of 16 explored students' knowledge and attitudes.

This review also identified some methodological shortcomings and biases in survey methods. For example, when asked about their general attitude towards only one specific model of consent, the public in opt-in countries reports higher endorsement for opt-out than when provided with alternative models. An explanation is that survey participants do not realize the disadvantages of one model until they can compare it with others. Generally, attitude questions with more response options, as well as more extensive verbal labelling of numbered response options, tend to be more reliable [51]. We also found a wide variation in the framing of questions on the system of consent, which also limits between-study comparisons.

Future survey research on this topic should include criteria as repetition of former questions and cross-sectional survey panels to increase the evidence and enhance their report standards for sampling and recruitment, as well as to providing sufficient background information for assessing the impact of media or public campaigns. To increase the validity and relevance of future research on this topic, we recommend investigators to ask respondents about all relevant policy options available and to ensure that respondents understand the meaning of each policy alternative. There is also a need for large international studies -including under-represented regions- using standardized methods to aid comparison and interpretation of survey questions.

\section{Conclusions}

Identifying and addressing public views towards the consent system for organ procurement is key in developing effective and ethical organ donation policies. This study provides the first comprehensive systematic review of available studies conducted in European countries on public knowledge and attitudes towards different models of consent for deceased organ donation, including presumed consent (opt-out), and expressed consent (opt-in).

Our findings show that people's awareness of the consent model, as well as their knowledge of the procedures to express consent or refusal to organ procurement, is lower in opt-out countries than in opt-in countries. Additionally, despite the general tendency in Europe and elsewhere to move from opt-in to opt-out policies, a majority of the public agree with opt-in regardless of the consent system in place in their own country. Moreover, they tend to prefer opt-in and mandatory choice to opt-out when two or more options are offered.

Lawmakers interested in modifying the consent system for organ donation can find in this review important insights as to how the public may understand and perceive such policy changes. A concern raised by this review is the lack of public awareness of the consent system in opt-out countries, since ignorance hinders people's autonomy regarding organ donation decision-making. Our review also stresses the importance of conducting standardized research on this topic.

\section{Competing interests}

The authors declare that they have no competing interests.

\section{Acknowledgments}

We thank Anja Marie Bornø Jensen for her contribution in the process of data extraction. We thank David Shaw for useful comments and recommendations. We also thank especially Fátima Al Mesri Rodríguez for her assistance in several parts of the process.

\section{Funding}

This study was conducted as part of the RESPONSE [Research on Ethical Strategies to Increase Organ Donation in Europe] project (FFI2015-62699-ERC) funded by the Spanish Ministry of Economy, Spain. The funding body had no role in the design of the study, data collection, data analysis, data interpretation, nor in writing the manuscript.

\section{Authors' contributions}

AMP and DRA designed and conducted the study and wrote the manuscript. JD gathered all the data about consent systems legislations in European countries. MM and SiSchi supervised the methodology as well as the interpretation and reporting of results, and together with JD, contributed to eligibility assessment, quality assessment, data extraction, and drafting the manuscript. MF, JR, ES, and SW contributed to eligibility assessment, quality assessment, and data extraction. GR contributed to drafting the report. All authors read and approved the final manuscript.

\section{References}

[1] Christie B. Scotland plans to move to opt-out system for organ donation. BM] 2017; 358:j3298. https://doi.org/10.1136/bmj.j3298.

[2] Iacobucci G. Proposals for opt-out organ donation launched for England. BMJ 2017; 359:j5764. https://doi.org/10.1136/bmj.j5764. 
[3] Nordfalk F, Olejaz M, Jensen AMB, et al. From motivation to acceptability: a survey of public attitudes towards organ donation in Denmark. Transplant Res 2016;5:5. https://doi.org/10.1186/s13737-016-0035-2.

[4] Saunders B. Opt-out organ donation without presumptions. J Med Ethics 2012;38: 69-72.

[5] European Commission. Eurobarometer 72.3: Public Health attitudes, Behavior, and Prevention. Version 1; October 2009; 2013. https://doi.org/10.3886/ICPSR32441.v1.

[6] Bastami S, Matthes O, Krones T, et al. Systematic review of attitudes toward donation after cardiac death among healthcare providers and the general public. Crit Care Med 2013;41:897-905. https://doi.org/10.1097/CCM.0b013e31827585fe.

[7] de Groot J, Vernooij-Dassen M, Hoedemaekers C, et al. Decision making by relatives about brain death organ donation: an integrative review. Transplantation 2012;93: 1196-211. https://doi.org/10.1097/TP.0b013e318256a45f.

[8] Haugland C, Eidsvik M. Factors influencing the relatives decision regarding organ donation in interaction with the intensive care nurses - a meta-synthesis. Published Online First: 9 May 2016 https://brage.bibsys.no/xmlui/handle/11250/2407227. (accessed 3 Feb 2017).

[9] Irving MJ, Tong A, Jan S, et al. Factors that influence the decision to be an organ donor: a systematic review of the qualitative literature. Nephrol Dial Transplant Off Publ Eur Dial Transpl Assoc - Eur Ren Assoc 2012;27:2526-33. https://oi.org/ $10.1093 /$ ndt/gfr683.

[10] Simpkin AL, Robertson LC, Barber VS, et al. Modifiable factors influencing relatives' decision to offer organ donation: systematic review. BMJ 2009;338:b991.

[11] Shah SK, Kasper K, Miller FG. A narrative review of the empirical evidence on public attitudes on brain death and vital organ transplantation: the need for better data to inform policy. J Med Ethics 2015;41:291-6. https://doi.org/10.1136/medethics2013-101930.

[12] Johnson E, Goldstein D. Do Defaults save lives? Science 2003;302:1338-9.

[13] Gimbel RW, Strosberg MA, Lehrman SE, et al. Presumed consent and other predictors of cadaveric organ donation in Europe. Prog Transplant 2003;13:17-23.

[14] Healy K. Do presumed-consent laws raise organ procurement rates. DePaul Rev 2005;55:1017.

[15] Abadie A, Gay S. The impact of presumed consent legislation on cadaveric organ donation: a cross-country study. J Health Econ 2006;25:599-620. https://doi.org/10. 1016/j.jhealeco.2006.01.003.

[16] Neto GB, Nunes da Silva E, Katarina Campelo A. The impact of presumed consent law on organ donation: an empirical analysis from quantile regression for longitudinal data. Working Paper of Public Health 2012;1(1). https://doi.org/10.4081/wpph. 2012.6769.

[17] Coppen R, Friele RD, Gevers SKM, et al. The impact of donor policies in Europe: a steady increase, but not everywhere. BMC Health Serv Res 2008;8:235. https://doi. org/10.1186/1472-6963-8-235.

[18] Coppen R, Friele RD, Gevers SKM, et al. Imagining the impact of different consent systems on organ donation: the decisions of next of kin. Death Stud 2010;34:835-47.

[19] Mossialos E, Costa-Font J, Rudisill C. Does organ donation legislation affect individuals' willingness to donate their own or their relative's organs? Evidence from European Union survey data. BMC Health Serv Res 2008;8:48. https://doi.org/10. 1186/1472-6963-8-48.

[20] Rithalia A, McDaid C, Suekarran S, et al. Impact of presumed consent for organ donation on donation rates: a systematic review. BMJ 2009;338:a3162.

[21] Bilgel F. The impact of presumed consent laws and institutions on deceased organ donation. Eur J Health Econ HEPAC Health Econ Prev Care 2012;13:29-38. https:/ doi.org/10.1007/s10198-010-0277-8.

[22] Bendorf A, Pussell BA, Kelly PJ, Kerridge IH. Socioeconomic, demographic and policy comparisons of living and deceased kidney transplantation rates across 53 countries. Nephrol Ther 2013 Sep;18:633-40.

[23] Shepherd L, O'Carroll RE, Ferguson E. An international comparison of deceased and living organ donation/transplant rates in opt-in and opt-out systems: a panel study. BMC Med 2014;12:131. doi:https://doi.org/10.1186/s12916-0140131-4.

[24] Willis BH, Quigley M. Opt-out organ donation: on evidence and public policy. J R Soc Med 2014 Feb;107:56-60.

[25] Hawkes N. Welsh opt-out law fails to increase organ donations. BMJ 2017;359: j5659. https://doi.org/10.1136/bmj.j5659.

[26] Palmer M. Opt-out systems of organ donation: International evidence review. Welsh Government Social Research; 2012http://gov.wales/statistics-and-research/opt-outsystems-of-organ-donation/?lang=en. (16/12/2017).

[27] Organ Donation Taskforce. The Potential Impact of an Opt out System for Organ Donation in the UK: an Independent Report from the Organ Donation Taskforce. http://webarchive.nationalarchives.gov.uk/+/http:/www.dh.gov.uk/en/ Publicationsandstatistics/Publications/PublicationsPolicyAndGuidance/DH_090312; 2008. (30/11/2017).

[28] Strech D, Synofzik M, Marckmann G. Systematic Reviews of Empirical Bioethics. J Med Ethics 2008;34:472-7.

[29] Dixon-Woods M, Cavers D, Agarwal S, et al. Conducting a critical interpretive synthesis of the literature on access to healthcare by vulnerable groups. BMC Med Res Methodol 2006;6:35.

[30] Morgan M, Kenten C, Deedat S, on behalf of the DonaTE Programme T. Attitudes to deceased organ donation and registration as a donor among minority ethnic groups in North America and the UK: a synthesis of quantitative and qualitative research. Ethn Health 2013;18:367-90. https://doi.org/10.1080/13557858. 2012.752073.

[31] British Medical Association. Two thirds of people support a 'soft' opt-out organ donation system, reveals new BMA survey. (Press release 28/02/2017) https://www. bma.org.uk/news/media-centre/press-releases/2017/february/two-thirds-ofpeople-support-an-optout-organ-donation-system. (16/12/2017).
[32] Fabre J, Murphy P, Matesanz R. Presumed consent: a distraction in the quest for increasing rates of organ donation. BMJ 2010;341:c4973. https://doi.org/10.1136/bmj. c4973.

[33] Boyarsky BJ, Hall EC, Deshpande NA, Ros RL, Montgomery RA, Steinwachs DM, et al. Potential limitations of presumed consent legislation. Transplantation 2012 Jan 27; 93:136-40.

[34] Fabre J. Presumed consent for organ donation: a clinically unnecessary and corrupting influence in medicine and politics. Clin Med 2014 Dec 1;14:567-71.

[35] McCartney M. When organ donation isn't a donation. BMJ 2017 Feb 28;356:j1028.

[36] Cohen C. The case for presumed consent to transplant human organs after death. Transplant Proc 1992;24:2168-72.

[37] Kennedy I, Sells RA, Daar AS, Guttmann RD, Hoffenberg R, Lock M, et al. The case for "presumed consent" in organ donation. The Lancet 1998 May 30;351:1650-2.

[38] English V, Sommerville A. Presumed consent for transplantation: a dead issue after Alder Hey? J Med Ethics 2003 Jun 1;29:147-52.

[39] Gill MB. Presumed consent, autonomy, and organ donation. J Med Philos 2004 Feb 1; 29:37-59.

[40] Veatch RM, Pitt JB. The myth of presumed consent: ethical problems in organ procurement strategies. Transplant Proc 1995;27:888-92.

[41] Truog RD. Consent for organ donation-balancing conflicting ethical obligations. New England Journal of Medicine 2008 Mar 20;358:1209-11.

[42] Bramhall S. Presumed consent for organ donation: a case against. Ann R Coll Surg Engl 2011;93:268-72.

[43] Farsides B. Respecting wishes and avoiding conflict: understanding the ethical basis for organ donation and retrieval. Br J Anaesth 2012;108:i73-9.

[44] MacKay D. Opt-out and consent. J Med Ethics 2015;41:832-5. https://doi.org/10. 1136/medethics-2015-102775.

[45] Hansen SL, Eisner MI, Pfaller L, et al. "Are You In or Are You Out?!" Moral appeals to the public in organ donation poster campaigns: a multimodal and ethical analysis. Health Communication 2017:1-15.

[46] Callender CO, Miles PV. Minority organ donation: the power of an educated community. J of the Am College of Surgeons 2010;210:708-15.

[47] MacKay D, Robinson A. The Ethics of Organ Donor Registration policies: Nudges and respect for Autonomy. The American Journal of Bioethics, The American journal of bioethics : AJOB 2016 Nov 1;16:3-12.

[48] Hamm D, Tizzard J. Presumed consent for organ donation. BMJ 2008;336:230

[49] Rosenblum AM, Li AH, Roels L, Stewart B, Prakash V, Beitel J, et al. Worldwide variability in deceased organ donation registries. Transpl Int 2012 Aug;25: 801-11.

[50] Rosenblum AM, Horvat LD, Siminoff LA, Prakash V, Beitel J, Garg AX. The authority of next-of-kin in explicit and presumed consent systems for deceased organ donation: an analysis of 54 nations. Nephrology Dialysis Transplantation 2011 Nov 25;27: 2533-46.

[51] Alwin DF, Krosnick JA. The reliability of survey attitude measurement: the influence of question and respondent attributes. Sociological Methods \& Research 1991;20: 139-81.

\section{Included studies}

[A1*] Bedi KK, Hakeem AR, Dave R, Lewington A, Sanfey H, Ahmad N. Survey of the knowledge, perception, and attitude of medical students at the University of Leeds toward organ donation and transplantation. Transplant Proc 2015 Mar;47: 247-60.

[A2] Coad L, Carter N, Ling J. Attitudes of young adults from the UK towards organ donation and transplantation. Transplant Res 2013 May 17;2:9

[A3] Decker O, Winter M, Brähler E, Beutel M. Between commodification and altruism: gender imbalance and attitudes towards organ donation. A representative survey of the German community. Journal of Gender Studies 2008 Sep 1;17:251-5.

[A4] Durczyński A, Dąbrowska A, Strzelczyk J. Organ transplantation remains taboo topic in polish families - small town youths survey results. Med Sci Tech 2011; 52:RA53-5.

[A5] Durczyński A, Pietrzak M, Strzelczyk J. Preliminary report from a prison survey: should prisoners be considered as organ donors? Ann Transplant 2013 Nov 8; 18:604-8.

[A6] Figueroa CA, Mesfum ET, Acton NT, Kunst AE. Medical students' knowledge and attitudes toward organ donation: results of a Dutch survey. Transplant Proc 2013 Aug;45:2093-7.

[A7] Gazibara T, Kovacevic N, Nurkovic S, Kurtagic I, Maric G, Kisic-Tepavcevic D, et al. To be or not to be an organ donor: differences in attitudes between freshmen and senior medical students. Cell Tissue Bank 2015 Sep;16:457-65.

A8] Harald J, Emeric E-Z, László H, Katalin SP, Gabor C, Brînzaniuc K. Organ donation and transplantation: what do the upcoming medical doctors think about? Romanian Journal of Bioethics [Internet] 2011;9 [cited 2017 May 11].

[A9] Healy G, Sharma K, Healy DG. Transplantation, multi-organ donation \& presumed consent: a 3 year survey of university students. Ir Med J 2009 Oct;102:297-8.

[A10] Katsari V, Domeyer PJ, Sarafis P, Souliotis K. Giving your last Gift: a Study of the Knowledge, Attitude and Information of Greek students regarding Organ Donation. Ann Transplant 2015 Jul 2;20:373-80.

[A11] Kobus G, Piotrowska J, Malyszko J, Bachorzewska-Gajewska H, Malyszko J. Attitudes of members of the Baptist Church toward organ transplantation. Transplant Proc 2014 Oct;46:2487-91.

[A12] Kobus G, Reszec P, Malyszko JS, Małyszko J. Opinions and attitudes of University students concerning Organ Transplantation. Transplant Proc 2016 Jun;48: 1360-4. https://doi.org/10.1016/j.transproceed.2016.01.045. 
[A13] Koźlik P, Pfitzner R, Nowak E, Kozynacka A, Durajski L, Janik L, et al. Correlations between demographics, knowledge, beliefs, and attitudes regarding organ transplantation among academic students in Poland and their potential use in designing society-wide educational campaigns. Transplant Proc 2014 Oct;46:2479-86.

[A14] Krekula LG, Malenicka S, Linder M, Tibell A. From words to action-influence of two organ donation campaigns on knowledge and formal decision making. Clin Transplant 2009 Jul;23:343-50.

[A15] Lauri MA. Metaphors of organ donation, social representations of the body and the opt-out system. Br J Health Psychol 2009 Nov;14:647-66.

[A16] Martínez-Alarcón L, Ríos A, Sánchez J, et al. Evaluation of the law of presumed consent after brain death by Spanish journalism students. Transplant Proc 2010;42: 3109-12. https://doi.org/10.1016/j.transproceed.2010.05.073A17.

[A17] Mekahli D, Liutkus A, Fargue S, Ranchin B, Cochat P. Survey of first-year medical students to assess their knowledge and attitudes toward organ transplantation and donation. Transplant Proc 2009 Mar;41:634-8.

[A18] Michalska E, Kołodziej K, Szymański D, Strzelczyk J. Students of the polish catholic theological seminars and the issue of organ transplantation. Ann Transplant 2010 Dec;15:56-60.

[A19] Nordfalk F, Olejaz M, Jensen AMB, Skovgaard LL, Hoeyer K. From motivation to acceptability: a survey of public attitudes towards organ donation in Denmark. Transplant Res 2016;5:5.

[A20] Nowak E, Pfitzner R, Koźlik P, Kozynacka A, Durajski L, Przybyłowski P. Current state of knowledge, beliefs, and attitudes toward organ transplantation among academic students in Poland and the potential means for altering them. Transplant Proc 2014 Oct;46:2509-18.

[A21] Nowak E, Pfitzner R, Koźlik P, Kozynacka A, Durajski L, Przybyłowski P. Organ Donor Cards-concepts versus reality: a study among academic students in Poland. Transplant Proc 2014 Oct;46:2519-29.

[A22] Pawłowicz E, Nowicki M. Knowledge about Legal Regulations regarding Organ Transplantation among High School and University students in Poland. Transplant Proc 2016 Jun;48:1350-3. https://doi.org/10.1016/j.transproceed.2016.01.068.

[A23] Randhawa G, Brocklehurst A, Pateman R, Kinsella S, Parry V. 'Opting-in or optingout?'-the views of the UK's faith leaders in relation to organ donation. Health Policy 2010 Jun;96:36-44.

[A24] Röcklinsberg H. The complex use of religion in decisions on organ transplantation.] Relig Health 2009 Mar;48:62-78.

[A25] Runarsdottir K, Olafsson K, Arnarsson A. Public attitudes towards presumed consent in organ donation in Iceland. Laeknabladid 2014 Oct;100:521-5.

[A26] Ryckman RM, Gold JA, Reubsaet A, van den Borne B. Value priorities and intention to register for posthumous organ donation in Dutch adolescents. J Soc Psychol 2009 Apr;149:213-27.

[A27] Schweda M, Wöhlke S, Schicktanz S. Understanding public skepticism toward organ donation and its commercialization: the important role of reciprocity. Transplant Proc 2009 Aug;41:2509-11.

[A28] Sharif A, Jawad H, Nightingale P, Hodson J, Lipkin G, Cockwell P, et al. A quantitative survey of Western Muslim attitudes to solid organ donation. Transplantation 2011 Nov 27;92:1108-14.

[A29] Sharp C, Randhawa G. UK Polish Migrant attitudes toward Deceased Organ Donation: Findings from a pilot Study. J Immigr Minor Health 2015 Aug;17:1157-62.

[A30*] Stadlbauer V, Steiner P, Schweiger M, Sereinigg M, Tscheliessnigg K-H, Freidl W, et al. Knowledge and attitude of ICU nurses, students and patients towards the Austrian organ donation law. BMC Med Ethics 2013 Aug 16;14:32.

[A31] Symvoulakis EK, Komninos ID, Antonakis N, Morgan M, Alegakis A, Tsafantakis E, et al. Attitudes to kidney donation among primary care patients in rural Crete. Greece BMC Public Health 2009 Feb 10;9:54.

[A32] Symvoulakis EK, Markaki A, Galanakis C, Klinis S, Morgan M, Jones R. Shifting towards an opt-out system in Greece: a general practice based pilot study. Int J Med Sci 2013;10:1547-51.

[A33] Symvoulakis EK, Rachiotis G, Papagiannis D, Markaki A, Dimitroglou Y, Morgan M, et al. Organ donation knowledge and attitudes among health science students in Greece: emerging interprofessional needs. Int J Med Sci 2014;11:634-40.

[A34] Webb G, Phillips N, Reddiford S, Neuberger J. Factors Affecting the Decision to Grant Consent for Organ Donation: a survey of adults in England. Transplantation 2015 Jul;99:1396-402.

[G1] Beaufort Research. Public Attitudes to Organ Donation: Baseline Survey [Internet]. Welsh Government Social Research; 2012 Report No.: 38/2012 http://gov.wales/ statistics-and-research/public-attitudes-organ-donation/?lang=en. (16/12/17).

[G2] Beaufort Research. Research to support Wales' organ donation opt-out proposal consultation [Internet]. Welsh Government Social Research; 2012 Report No:14/ 2012 http://gov.wales/statistics-and-research/research-support-organ-donationproposal/?lang=en. (16/12/17).
[G3] Beaufort Research. Survey of Public attitudes to Organ Donation: Wave 2 [Internet]. Welsh Government Social Research; 2013. Report No.: 66/2013. http://gov.wales/ statistics-and-research/public-attitudes-organ-donation/?lang=en (16/12/17).

[G4] Beaufort Research. Evaluation of the Human Transplantation (Wales) Act: Qualitative Study of Public Attitudes [Internet]. Welsh Government Social Research; 2014 Report No.: 87/2014 http://gov.wales/statistics-and-research/evaluation-humantransplantation-wales-act/?lang=en. (16/12/17).

[G5] Beaufort Research. Survey of Public attitudes to Organ Donation: Wave 3 [Internet] Welsh Government Social Research; 2014 Report No.: 66/2013 http://gov.wales/ statistics-and-research/public-attitudes-organ-donation/?lang=en. (16/12/17).

[G6] Beaufort Research. Survey of Public attitudes to Organ Donation: Wave 4 and 5 [Internet]. Welsh Government Social Research; 2014. Report No.: 102/2014. http:// gov.wales/statistics-and-research/public-attitudes-organ-donation/?lang=en $(16 / 12 / 17)$.

[G7] Beaufort Research. Survey of Public attitudes to Organ Donation: Wave 6 and 7 [Internet]. Welsh Government Social Research 2015 Report No.: 31/2015 http://gov. wales/statistics-and-research/public-attitudes-organ-donation/?lang=en. (16/12/ 17).

[G8] Beaufort Research. Survey of Public attitudes to Organ Donation: Wave 8 and 9 [Internet]. Welsh Government Social Research; 2015. Report No.: 67/2015. http://gov. wales/statistics-and-research/public-attitudes-organ-donation/?lang=en (16/12/ 17).

[G9] Beaufort Research. Survey of Public attitudes to Organ Donation: Wave 10, 11 and 12 [Internet]. Welsh Government Social Research 2016 Report No.: 58/2016 http:// gov.wales/statistics-and-research/public-attitudes-organ-donation/?lang=en. $(16 / 12 / 17)$.

[G10] BZgA. Einstellung, Wissen und Verhalten der Allgemeinbevölkerung zur Organund Gewebespende [Internet]. Bundeszentrale für gesundheitliche Aufklärung: 2013 Aug. https://www.organspende-info.de/infothek/studien (16/12/17).

[G11] BZgA. Knowledge, Attitude and Behaviour of the General Public Regarding Organ and Tissue Donation [Internet]. Bundeszentrale für gesundheitliche Aufklärung; 2015 Dec. https://www.organspende-info.de/infothek/studien (16/12/17).

[G12] Eenvandaag Opiniepanel. Onderzoek: "Orgaandonatie" [Internet]. 2014 Oct [cited 2017 May 29]. http://www.eenvandaag.nl/uploads/doc/Rapport \%20orgaandonatie_1.pdf (16/12/17).

[G13] Harris Interactive. Sondage: les Français et le don d'organes [Internet]. M6; 2016 Mar. http://harris-interactive.fr/opinion_polls/les-francais-se-declarent-prets-audon-dorgane-mais-en-meconnaissent-le-cadre-juridique/ (16/12/17).

[G14] ICM Research. BBC Wells poll [Internet]. 2012. http://news.bbc.co.uk/2/shared/bsp/ hi/pdfs/29_2_12_bbcwalespoll.pdf (16/12/17).

[G15] Panteia Registratiesystemen voor orgaandonatie Maatschappelijk draagvlak en effectiviteit [Internet]. 2014 Sep. https://www.rijksoverheid.nl/documenten/ rapporten/2014/09/29/registratiesystemen-voor-orgaandonatie-maatschappelijkdraagvlak-en-effectiviteit (16/12/17).

[G16] PHA. Organ donation: Public attitudes and stakeholder engagement in Northern Ireland [Internet]. Northern Ireland: Public Health Agency; 2013 Oct. http:// www.publichealth.hscni.net/publications/organ-donation-public-attitudes-andstakeholder-engagement-northern-ireland-2013 (16/12/17).

[G17] R\&S. Contribution à la réflexion sur le don d'organes en France [Internet] Recherches \& Solidarités, France Adot; 2009 mai. https://www.france-adot.org/ images/pj/283p1_Synthese-Contribution-R\%26S-Don-dOrganes.pdf (16/12/17).

[G18] Social Market Research. Evaluation of a Public Information Campaign on Organ Donation [Internet]. Northern Ireland: Public Health Agency; 2015 Feb. http://www. publichealth.hscni.net/publications/evaluation-public-information-campaignorgan-donation (16/12/17).

[G19] Nipo TNS. Draagvlak orgaandonatie: Kennis, houding en gedrag van Nederlanders NIGZ - Donorvoorlichting ; 2009 August.

[G20] Nipo TNS. Draagvlak orgaandonatie, 1-meting: Kennis, houding en gedrag van Nederlanders; 2011 Sep.

[G21] Usurv. Survey about the proposed changes in UK law on organ donation [Internet]. Kidney Research UK; 2012 Mar. https://www.usurv.com/Ck-QDAABF (16/12/17).

[G22] Welsh Assembly Government. Options for changes to the organ donation system in Wales: Consultation paper. 2009 May.

[G23] YouGov. ITV Welsh barometer [Internet]. ITV; 2015 Junhttps://yougov.co.uk.

[G24] YouGov. The Times organ Donation and Sugar (Scotland) [Internet]. The Times; 2016 Feb. https://yougov.co.uk/ (16/12/17).

[G25] The Scottish Government. Organ and Tissue Donation and Transplantation: Analysis of Responses. http://www.gov.scot/Resource/0052/00521592.pdf (16/12/17).

[G26] Eenvandaag Opiniepanel. Onderzoek: "Draagvlak voor nieuwe donorwet" [Internet]. 2016 Sept. https://eenvandaag.avrotros.nl/fileadmin/editorial/docs/ rapportagenieuwedonorwet.pdf (10/08/18). 